er to design carefully research studies to answer these important questions. Studies should be performed on large numbers of workers with different job descriptions to determine the validity, reliability, and outcome of fit testing using N-95 and other respirators. Comparing time, cost, and outcome of functional quick fit testing, fit checking, and education alone with traditional fit testing would be useful. Determining the necessity or benefit of medical screening prior to fit testing would be useful as well. If carefully designed studies show substantial validity and benefit of fit testing, then it is much easier to justify the substantial resource involved. However, if the data show no benefit, NIOSH and OSHA should not mandate these components in all respiratory protection programs. For these studies to take place, funding should be made available to determine the validity, consistency, and outcome of fit testing with N-95 respirators in healthcare settings. The goal of such research studies would be to answer these questions systematically and to contribute to improving the occupational health and safety of healthcare workers.

\section{REFERENCES}

1. Hannum D, Cycan K, Jones L, Sterwart M, Markowitz SM, Wong ES. The effect of respirator training on the ability of healthcare workers to pass a qualitative fit -test. Infect Control Hosp Epidemiol 1996;17:636-640.
2. Hodous TK, Coffey CC. The role of respiratory protective devices in the control of tuberculosis. Occup Med 1994;9:631657. Review.

3. Nardell EA. Environmental control of tuberculosis. Med Clin North Am 1993;77:1315-1334. Review.

4. Jarvis WR, Bolyard EA, Bozzi CJ, et al. Respirators, recommendations, and regulations: the controversy surrounding protection of health care workers from tuberculosis. Ann Intern Med 1995;122:142-146.

5. Chen S, Vesley D, Brousseau L, et al. Evaluation of single-use masks and respirators for protection of health care workers against mycobacterial aerosols. Am J Infect Control 1994;22:6574 .

6. Vesley DL. Respiratory protection devices. Am J Infect Control 1995;23:165-168.

7. Adal KA, Anglim AM, Paulumbo CL, Titus MG, Coyner BJ, Farr BM. The use of high-efficiency particulate air-filter respirators to protect hospital workers from tuberculosis. $N$ Engl J Med 1994;331:169-173.

8. Nettleman MD, Fredrickson M, Good NL, Hunter SA. Tuberculosis control strategies: the cost of particulate respirators [see comments]. Ann Intern Med 1994;121:37-40.

9. Rosenstock L. 42 CFR Part 84: respiratory protective devices implications for tuberculosis protection. Infect Control Hosp Epidemiol 1995;16:529-531.

10. Occupational Safety and Health Administration. OSHA enforcement policy and procedures for occupational exposure to tuberculosis. Infect Control Hosp Epidemiol 1993;14:694-699.

11. Fridkin SK, Managan L, Bolyard E, Jarvis WR. SHEA-CDC TB survey part I: status of TB infection control programs at member hospitals, 1989-1992. Infect Control Hosp Epidemiol 1995;16:129-134.

12. Fridkin SK, Managan L, Bolyard E, Jarvis WR. SHEA-CDC TB survey, part II: efficacy of TB infection control programs at member hospitals, 1992. Society for Healthcare Epidemiology of America. Infect Control Hosp Epidemiol 1995;16:135-140.

\title{
Repeat Fit Testing Not Routinely Required
}

\section{Michael D. Decker, MD, MPH}

As noted recently in the SHEA Newsletter (volume 6, number 2, Summer 1996), OSHA has clarified that fit testing of respirators for protection from tuberculosis need not be repeated routinely (eg, annually). In an October 1992 letter responding to an inquiry, Roger A. Clark, Acting Director, OSHA Directorate of
Compliance Programs, wrote, "You ask how often the fit test indicated at 29 CFR 1910.134 (e) (5) (i) must be provided for employees who wear a negative-pressure, air-purifying respirator. Fit testing must be repeated whenever respirator design or facial changes occur that could affect the proper fit of the respirator. Please bear in mind that the OSHA standards for asbestos, arsenic, lead, and acrylonitrile require that respirators be fit tested at least semiannually, and the standards for benzene and formaldehyde require that respirators be fit tested at least annually."

Thus, repeat fit testing is required only in the event of a change in the respirator or a change in the employee (injury, surgery, major weight change, etc) that could affect respirator fit. 